\title{
Designing a Tool Related to Strategic Control in Hospital Centers
}

\author{
Jamil Sadeghifar $^{1}\left(\right.$ D) Mehdi raadabadi $^{2}$ (D) Reza Jorvand $^{3}($ iD $)$ Mehdi Jafari $^{4 *(D)}$
}

\begin{abstract}
Introduction: One of the important requirements of health care systems in providing quality and safe services is developing appropriate strategies, effective implementation of these strategies, and controlling the results of the implementation. The design and implementation of a strategic control system ensures that the organization's performance in relation to the strategic management steps is correct. The purpose of this study was to identify and explore factors related to strategic control in the hospital systems.

Methods: This analytical study was conducted in 2016 on 425 experts from the Strategic Planning Committee of educational hospitals affiliated to Tehran and Iran University of Medical Sciences and experts in the field of strategic planning. Data were collected using a researcher-made questionnaire. Data analysis was performed based on exploratory factor analysis with SPSS 21 software. Data were collected using a researcher-made questionnaire. Data analysis was conducted based on exploratory factor analysis using the SPSS software version 21.
\end{abstract}

Results: Results of the exploratory factor analysis showed that factors related to strategic control in the hospital system were five independent factors including infrastructure and external support (variance percentage 13.3), vision clarification and strategy and conversion to action (variance percentage 12.2), sharing and establishing data and knowledge flow (variance percentage 10.3), planning and setting goals (variance percentage 9.2), and strategic learning and feedback (variance percentage 7.5).

Conclusion: The results of the study showed that the strategic control questionnaire used in this study could be useful as a tool for assessing the accuracy of designing, implementation, monitoring, and evaluation of strategies in the hospital systems.

Keywords: Strategic Control, Strategic Planning, Factor Analysis, Hospital, Iran

•Received: 21/Dec/2019 •Modified: 01/March/2020 •Accepted: 14/March/2020

1. Associate Professor, School of Health, Ilam University of Medical Sciences, Ilam, Iran, jamil.sadeghifar@gmail.com

2. MSc in Medical Education, Shahid Sadoughi University of Medical Sciences, Yazd, Iran, mehdiraadabadi@gmail.com

3. Assistant Professor, School of Health, Ilam University of Medical Sciences, Ilam, Iran, jorvand$\mathrm{r} @$ medilam.ac.ir

4. Professor, School of Health Management and Information Sciences, Iran University of Medical Sciences, Tehran, Iran; Corresponding author, mjafari@iums.ac.ir 


\section{طراحى ابزار عوامل مرتبط بر كنترل استراتزيك در مراكز بيمارستانى}

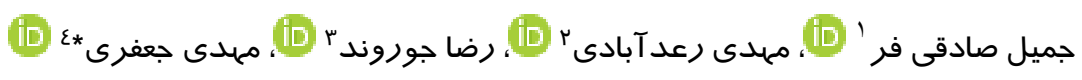

קكيده

مقدمه: يكى از ضرورتهاى مهم نظامهاى مراقبت سلامت در ارائه خدمات باكيفيت و ايمن، تدوين استراتزىهاى مناسب،

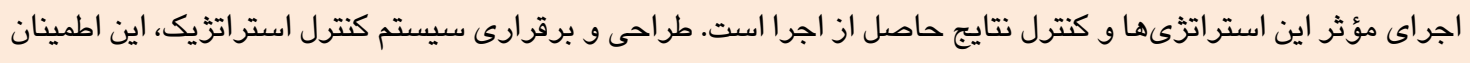

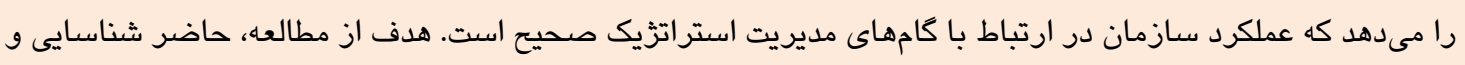

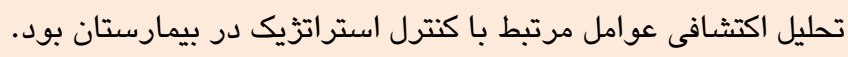

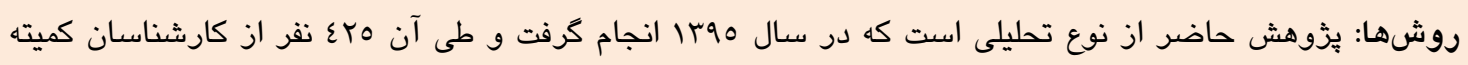

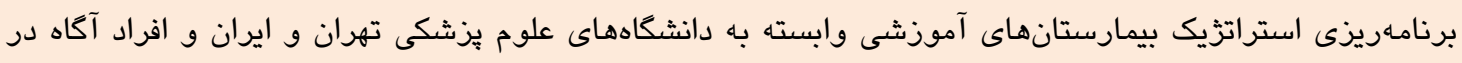

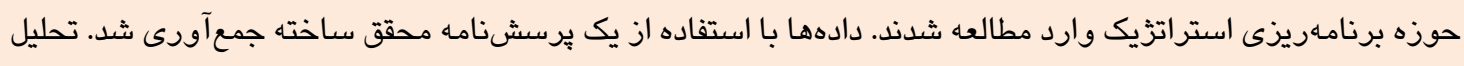

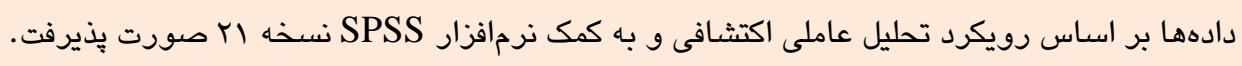

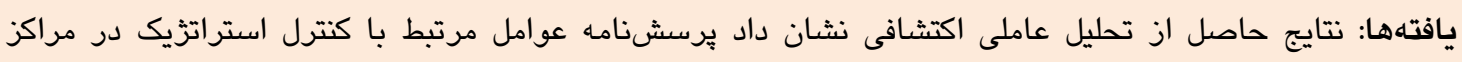

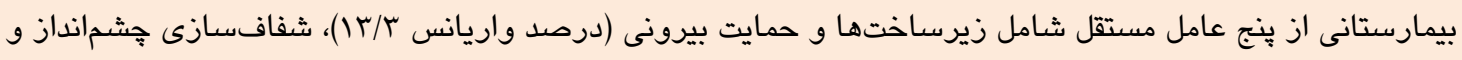

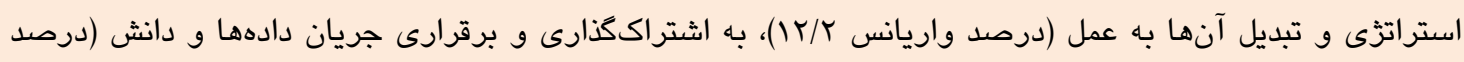

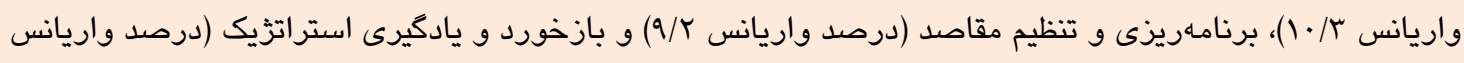

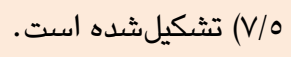

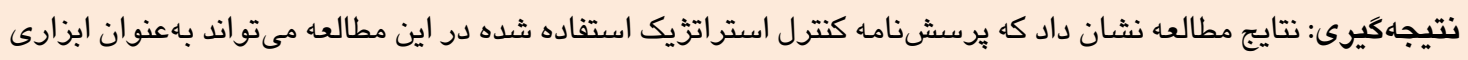

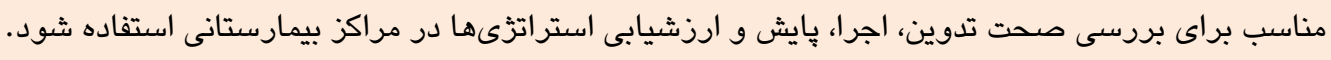

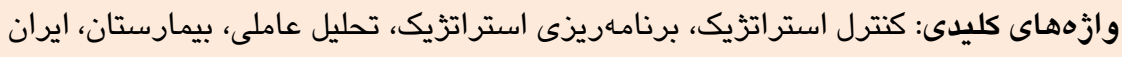

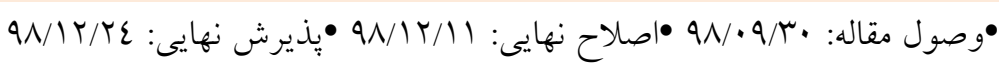

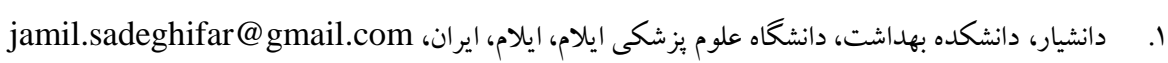

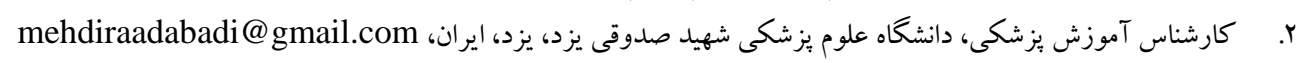

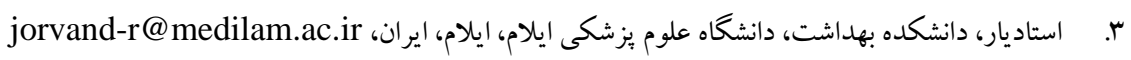

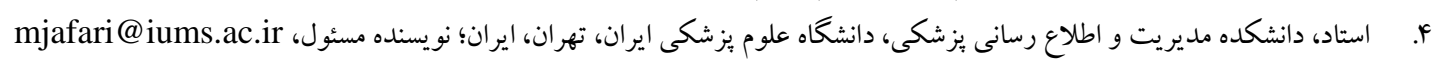


بيمارستانى و رضايت بيماران كه هدف نهايى بيمارستان

است، محقق نمىشود. [9]

كنترل استراتزيكك بهمنظور كمكك به مديران ارشد سازمان در اهر جهت ارزيابى استراتزى و هدايت آن بهسوى اهداف از ييش

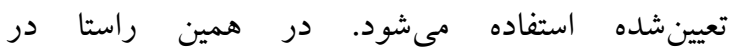

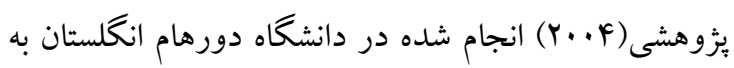
كنترل استراتزيكك بهعنوان يكى از اثربخش ترين سيستمهاى

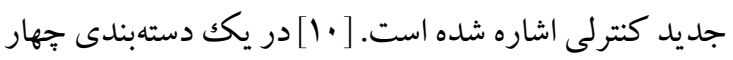
نوع كنترل استراتزيكك شامل كنترل قبل از اجرا بهمنظور بررسى نظاممند و مداوم اقدامات در حين برنامهريزى و

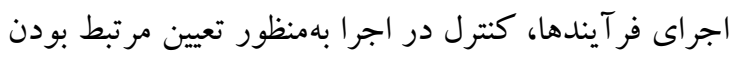

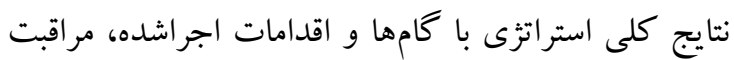
استراتزيكك در جهت يايش طيف وسيعى از اتفاقات تهديد كننده استراتزى سازمان در درون و بيرون از سازمان و كنترل مبتنى بر اخطارهاى ويزٔه بهمنظور بررسى مجدد كامل دئل و اغلب سريع استر اتزى سازمان با توجه به حو ادث غيرمنتظره

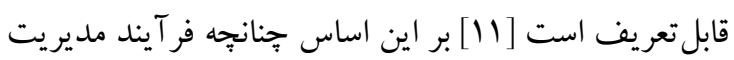

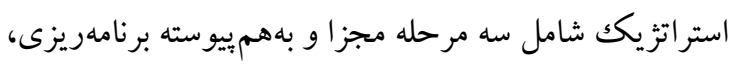

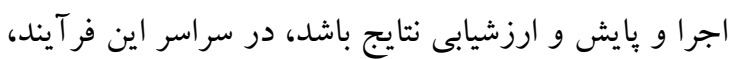
تأكيد بر كنترل استر اتزيكك به معناى داشتن نوعى نشاه نقاد نقادانه

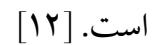

در مراكز بيمارستانى ايران، جالشها و نارسايىهايى از قبيل حاكم بودن سلايق مديران در اداره بيمارستانها، كمبود تصميم گيرىهاى مديريتى مبتى بر شو اهد، ضعف در تدوين، اجراو ارزشيابى اهداف و برنامههاى سازمان، نقصان در نظام

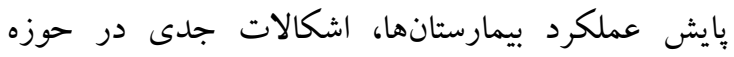
مديريت عملكرد كار كنان و مسائلى ازايندست، وجود دارد. نكته حائز اهميت ديخر اين است كه بيمارستان در مورد

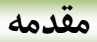

امروزه سازمانها با جالشهاى وسيعى براى بقا در بازارهاى نايايدار و رقابتى جهانى مواجه هستند. سازمانها در راستاى غلبه بر اين خالشها و كسب موفقيت در ميدان رقابت، بايد از نوعى برنامهريزى بهره كيرند كه آيندهنگر و محيط كرا باشد بهطورى كه ضمن شناسايى عو امل و تحولات محيطى، در يكك افق زمانى بلندمدت تأثير آنها بر سازمان و نحوه تعامل سازمان با آنها را مشخص كند. [1] بقا و دوام سازمانها و همجنين توسعه آنها نيازمند درك به بهنام فرصتهاى محيطى، تغييرات در بازار و برنامهريزى استر اتزيكك و انتخاب استراتزى مناسب و اثربخش است. [Y] برنامهريزى استراتزيكك بهعنوان يكك مفهوم از اوايل دهه 199 مطرح شد و در طول ساليان اخير درجه مختلفى از توجهها به سمت آن معطوف شده است. [ب] برنامهريزى استراتزيك بهطور عملى در سازمانهاى مراقبت سلامت به به سله استفادهشده است و به نظر مىرسد يكك ابزار مناسب در ميان

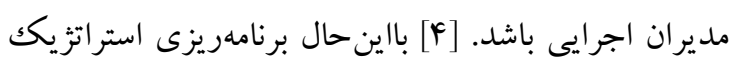
بهتنهايى ضامن دستيبى به اهداف نيست و جنانجه استراتزىهاى تدوينشده از اثربخشى لازم برخوردار نباشد،

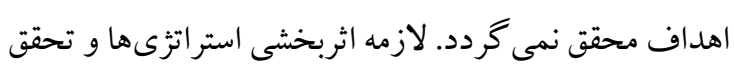
اهداف تدوينشده در برنامه، استفاده از رويكردهاى تدوين استراتزى مبتنى بر مدلهاى رياضى و بينش مديريتى است.

از طرفى برخلاف تدوين استراتزى، اجر اى استراتثى بهتنهايى توسط مديران به دست نخواهد آمد. بلكه اجراى آن نيازمند همكارى همه جانبه كليه افراد يكك سازمان است. [9] همجينين

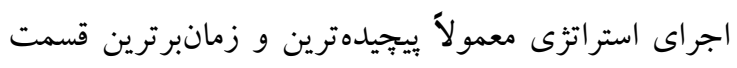
تدوين مديريت استراتزيكك بوده، درحالى كه تدوين استراتزى تنها يكك فعاليت اوليه فكرى و خلاق است. [V]

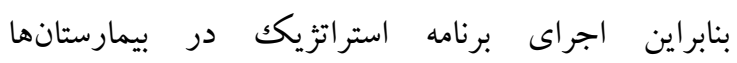
بهخودى خود صورت نخواهد كرفت و لازمه آن توجه به به بئ

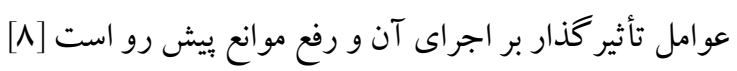

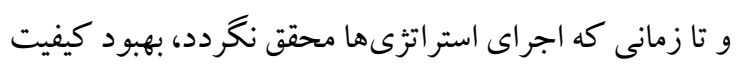


ابتدا فهرست عناصر مرتبط با سيستم كنترل استراتزيكك در بيمارستان بر اساس مرور نظاممند و مطالعه كيفى استخراج شد و اين عناصر در قالب يكك برسشنامه تنظيم گرديد. روايى يرسشنامه اوليه با FF FF خبر كان حوزه مديريت استراتزيكك با نسبت روايى محتوايى بررسى شد. جهت اطمينان از (Content Validity Ratio) اينكه مهمترين و صحيحترين محتوا (ضرورت مولفه) انتخابشده است از شاخص نسبت روايى محتوا استفاده مى گردد. جهت تعيين نسبت روايى محتوا بهصورت كمى از تعدادى از متخصصين و صاحبنظران استفاده مىشود تا در مورد هر كدام از مولفههاى ابزار يا سنجه مورداستفاده به سه طيف شامل ضرورى است، مفيد اما ضرورى نيست و

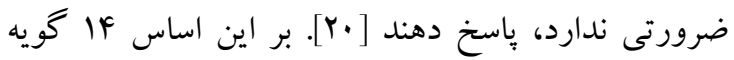

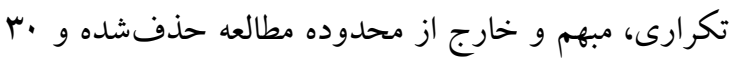

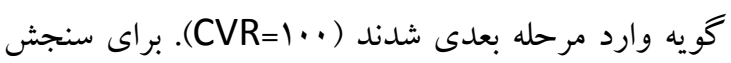
هايايى نيز از روش همسانى درونى با محاسبه ضريب آلفاى

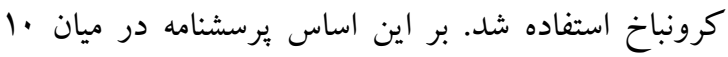
درصد حجم نمونه (·ه نفر خارج از شركت كنندكان در مطالعه) در فاصله زمانى دوهفته دو بار توزيع شد و سيس ضريب آلفاى كرونباخ محاسبه گرديد (^/ • = Q). هدف از انتخاب فاصله زمانى دوهفتهاى، كاهش احتمال تأثيرات محيطى بود كه ممكن است روى ياسخ شر كت كنند كان تأثير

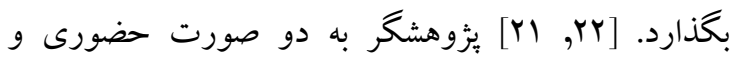
الكترونيكى برسشنامهها را در اختيار نمونهاى مطالعه قرارداد. با توجه به نياز به يكزمان مناسب براى تمركز بر سؤالات، به مدت يكك هفته براى تكميل برسشنامهها مهلت داده شد. در مورد برسشنامههايى كه بهصورت الكترونيكى ارسال شد، در صورت عدم باز گشت پِرسشنامه يس از يك هفته، ايميل ياد آور ارسال گرديد. جهت تحليل دادهها از نرمافزار SPSS ويرايش اب استفاده شد. اين نرمافزار با استفاده از همبستخى و كوواريانس بين متغيرهاى اندازه گيرى شده، مىتواند مقادير بارهاى عاملى و واريانس ها را بر آورد يا استنباط كند. در انجام تحليل عاملى، ابتدا بايد از اين مسئله اطمينان حاصل شود كه مىتوان
اساس آن سه مرحله تدوين برنامه، اجراى برنامه و يايش و ارزشيابى نتايج حاصل از اجراى برنامه را در قالب نظام كنترل استر اتزيك بررسى و بازبينى شود.

\section{روشها}

در مطالعه حاضر كه به روش تحليلى در سال هوسا انجام شد، بهمنظور تعيين عوامل مرتبط با كنترل استراتزيكك در بيمارستانها از روش تحليل عاملى اكتشافى استفاده شد. از اين روش بهمنظور يى بردن به متغيرهاى زيربنايى يكك يديده يا تلخيص مجموعهاى از دادهها استفاده مىشود. تحليل عاملى، يكك فن آمارى است كه در علوم انسانى كاربرد فراوان دارد و اكثراً بهعنوان روشى براى كاهش تعداد متغيرها به تعداد كمى از عوامل كه توصيف كنندة بيشترين ميزان واريانس هستند، شناخته شده است. [IF] جامعه يُزوهش شامل كارشناسان كميته برنامهريزى استراتزيك بيمارستانهاى آموزشى وابسته به دانشگاههاى علوم يزشكى تهر ان و ايران و افراد آكاه در حوزه برنامهريزى استراتزيكك كميته برنامهريزى استراتزيكك در بيمارستانهاى مورديزوهش و متصديان حوزه موردمطالعه در ستاد دانشگاه علوم بزشكى تهران و ايران و وزارت بهداشت بودند. معيار ورود نمونهها دارا بودن سابقه اجرايى در تدوين برنامه استراتزيك و كذراندن دوره آموزشى مرتبط با برنامه استراتزيكك بود. افرادى كه نيروى طرحى و يا شركتى بودند از مطالعه حذف شدند. نمونه گيرى در اين مرحله بهصورت طبقهاى و در درون طبقات بهصورت تصادفى ساده بود. در مورد حجم نمونه موردنياز براى تحليل عاملى، توافق كلى وجود ندارد. بسيارى از يثزوهشخران حداقل حجم نمونه را r... مرجع [11 [V] مطالعه كومرى و لى [19] را در اين مورد بهعنوان راهنماى حجم نمونه، مورد استناد قرار مىدهند. بر

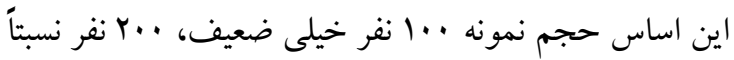

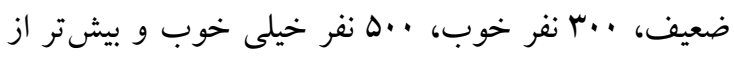
.... انفر، بسيار عالى است؛ بر اين اساس در مطالعه حاضر، حجم نمونه · ․ نفر در نظر گرفته شد. 
ساير مشخصات دمو گرافيك شركت كنندگان در جدول شماره يكك آورده شده است.

جدول 1: مشخصات دمو كر افيك شر كت كنند

ئزوهش

\begin{tabular}{|c|c|c|c|c|}
\hline درصد & و اوانى & متغير & & 6 \\
\hline$\Delta \Lambda / \Lambda$ & ro. & مرد & جنس & 1 \\
\hline$F \mid / r$ & IVD & زن ان & & \\
\hline $9 / 4$ & f. & كارشناسى & سطح تحصيلات & $r$ \\
\hline r $/ \Lambda$ & 190 & كارشناسى ارشد & & \\
\hline$\Delta / V$ & YF & د كتر اى حرفهاى & & \\
\hline$\mu / \mu$ & rr & دكتراى تخصصى & & \\
\hline $\mid F / \Lambda$ & $9 \pi$ & يِاسخ نداده & & \\
\hline$F / V$ & $r$. & وزارت بهداشت & سازمان محل & $r$ \\
\hline$r \Delta / q$ & 11. & دانشگاه & خدمت & \\
\hline$\Delta \Delta / \mu$ & THD & بيمارستان & & \\
\hline $1 \cdot 19$ & FD & ساير & & \\
\hline$r / \Delta$ & 10 & ״ِاسخ نداده & & \\
\hline $\mathrm{rV} / \mathrm{V}$ & 19. & زير ه سال & سابقه خدمت & $\varepsilon$ \\
\hline $9 / 4$ & f. & 9تا • اسال & & \\
\hline$r / \Delta$ & 10 & 11 تا ها سال & & \\
\hline $1 / r$ & $\Delta$ & بالاتر از اب سال & & \\
\hline YA/Y & $r \cdot \Delta$ & ياسخ نداده & & \\
\hline $1 \Lambda / \Lambda$ & $\wedge$. & هيات علمى & وضعيت شغلى & 0 \\
\hline$V \cdot 19$ & r... & غير هيات علمى & & \\
\hline $1 \cdot 19$ & Fo & ياسخ نداده & & \\
\hline
\end{tabular}

در اين مطالعه مقدار KMO برابر 9/. به دست آمد كه بيانگر

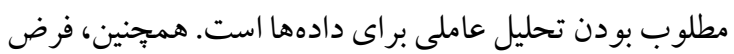

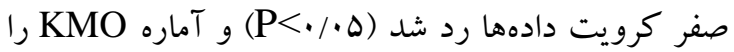

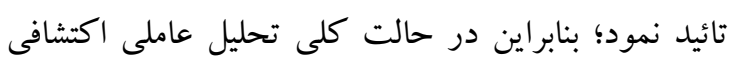
براى دادههاى حاضر مدل مناسبى ارائه داد. در جدول دو مقادير ارزش ويزه ارائهده است. ارزش ويزه مده مانه ميزان وارايانس تبيين شده بهوسيله هر عامل را بيان مى كند.

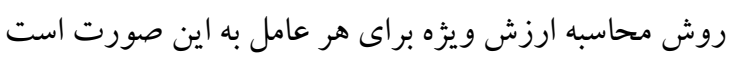

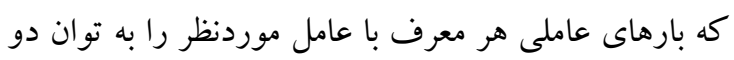

دادههاى موجود را براى تحليل استفاده نمود. با استفاده از آزمون بارتلت مى توان از كفايت نمونه گيرى، اطمينان حاصل نمود. اين شاخص در دامنه صفرتا يكك قرار دارد. اكر مقدار شاخص نزديكك به يكك باشد، دادههاى موردنظر براى تحليل

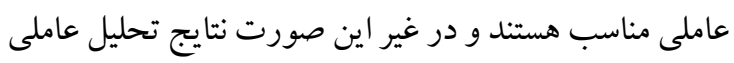

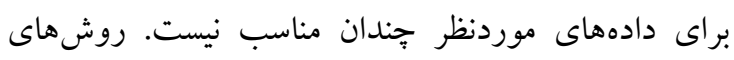

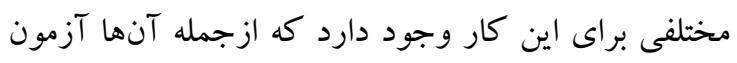
KMO است و مقدار آن همواره بين صفرتا يكك در نوسان است. درصورتى كه مقدار KMO كمتر از ه/ • باشد، دادهها براى تحليل عاملى، مناسب نخواهند بود و اخر مقدار آن بين

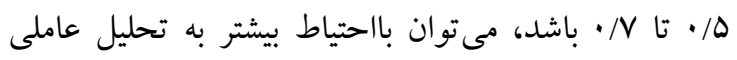

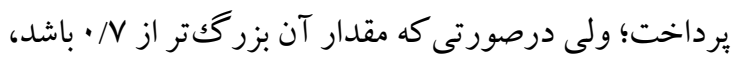

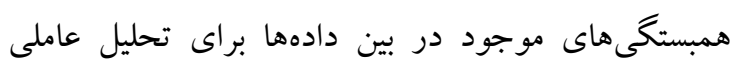

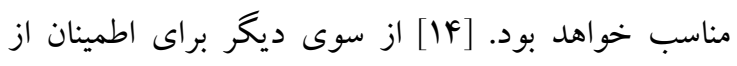

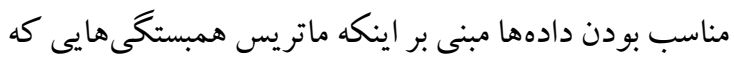

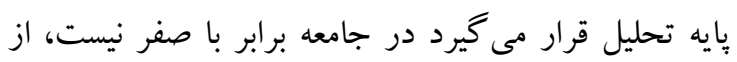
آزمون بارتلت استفادهده است. به عبارتى با استفاده از

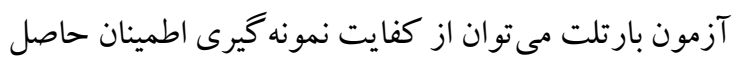
نمود. جهت محاسبه ميانخين ها با توجه به طيف ليكرت بنج

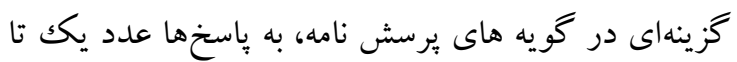

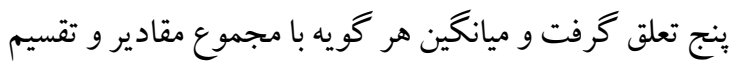

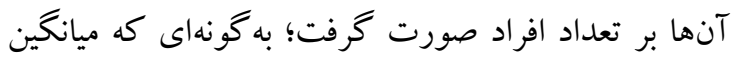
حاصل شده عددى بين يكك تا ينج بود و كمترين و بيشترين ميانگين نيز بين همين مقدار در تغيير بود.

\section{يافته ها}

نتايج مطالعه نشان داد كه اكثر شركت كنند كان، مرد ( درصد) و داراى مدركى كارشناسى ارشد (N/N درصدم)

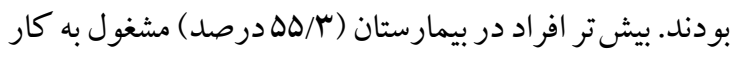
بودند و از بين نيمى از افراد كه اطلاعات مربوط به سابقه

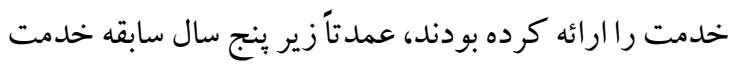

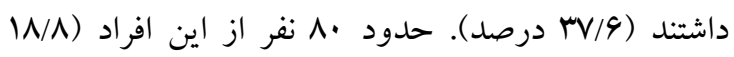
درصد) نيز در قالب هيات علمى، مشغول به فعاليت بودند. 
عامل اول: زيرساخت ها و حمايت بيرونى، شامل گويه هاى )،

D

عامل دوم: شفاف سازى جشمانداز و استراتزى و تبديل آنها به

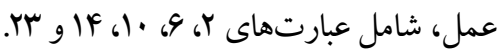
عامل سوم: به اشتراكك گذارى و برقرارى جريان دادهها و

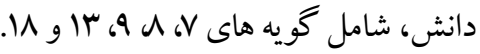

عامل جهارم: برنامهريزى و تنظيم مقاصد شامل گويه هاى ل1) r. عامل ينجم: بازخورد و ياد گيرى استراتزيك شامل گويه هاى

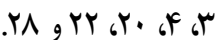

جهت شناسايى مهمترين و مؤثرترين مؤلفههاى مرتبط با

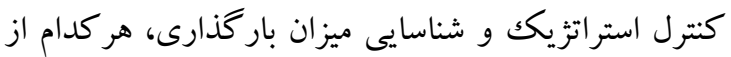

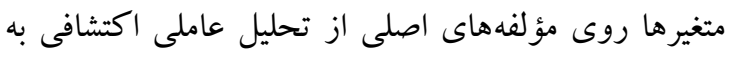

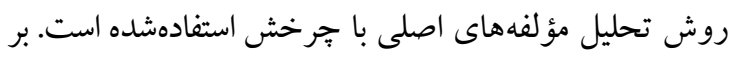

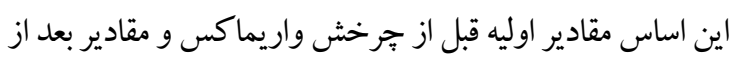
جرخش واريما كس در جدول سه ارائهده است. بر اساس مقادير

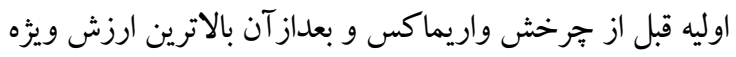

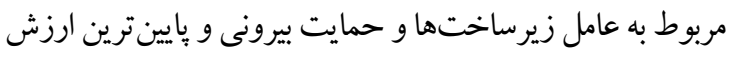

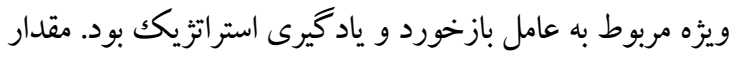
ويزه ميزان وارايانس تييين شده بهوسيله هر عامل را بيان مى كند و نسبتى از واريانس كل متغييرهاست كه آن عامل تبيين مى كند.

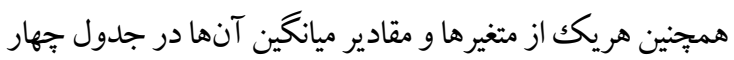

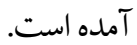
از آزمون سنگكريزه براى انتخاب تعداد مناسب عاملها در تحليل عاملى اكتشافى از روى مقادير ويزه استفاده مى شود. در اين نمودار بر اي انتخاب تعداد عامل هاى مناسب، مىتوان هم از مقادير ويزه بزركت تر از يكك و هم از نقطهاى استفاده كرد كه در آن، خط منحنى دجار كاهش شديد مى شى دود نتايج

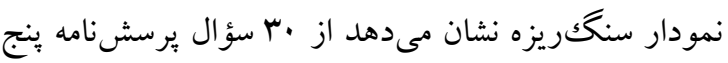
عامل تشكيلشدهاند كه در شكل يك نمايش دادهشده است.
(مجذور بارهاى عاملى) مىرسانيم سيس آنها را باهم جمع

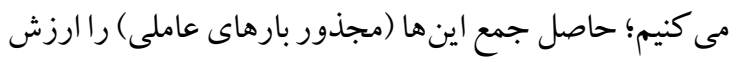

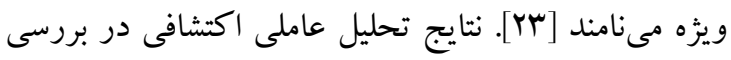

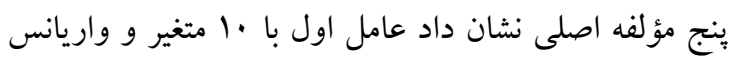

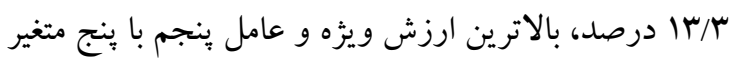

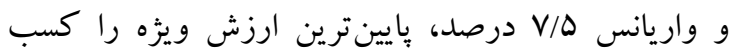

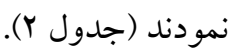

\section{جدول r: نتايج تحليل اكتشافى براى شناسايى}

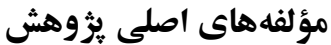

\begin{tabular}{|c|c|c|c|c|c|}
\hline وزئ & واري & واري & تعداد & مؤلفه اصلى & 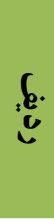 \\
\hline f & $\mid r / r$ & $r Y / \Lambda$ & 1. & زمايت بيرونى & 1 \\
\hline$r / v$ & $I r / r$ & 9 & $\Delta$ & ششفاف & $r$ \\
\hline$r / l$ & $1 \cdot / r$ & $\Delta / \mu$ & $\Delta$ & و به برقادراك كذارى جريان & $r$ \\
\hline$r / \Lambda$ & $9 / r$ & $F / \mu$ & $\Delta$ & مقاصدامهريزى و تنظيم & F \\
\hline$r / r$ & $V / \Delta$ & $F / r$ & $\Delta$ & بازخوردو ياد & $\Delta$ \\
\hline $10 / 1$ & $\Delta r / \Delta$ & $\Delta r / \varphi$ & $r$. & جمع & \\
\hline
\end{tabular}

بر پيايه ماتريس ساختار عاملها، مجموعه عبارتهايى كه بهطور مشترك با يكك عامل همبسته بوده، به اين شرح تشكيل يك سك يارهتست مىدهند و به ترتيب بيشترين بار عاملى، استخراج و نام-

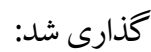


جميل صادقىفر و همكاران

جدول ب: كل واريانس تبيين شده مؤلفههاى يزوهش

\begin{tabular}{|c|c|c|c|c|c|c|}
\hline \multicolumn{3}{|c|}{ مقادير بعد از جرخش واريماكس } & \multicolumn{3}{|c|}{ مقادير اوليه قبل از جرخش واريماكس } & \multirow[b]{2}{*}{ 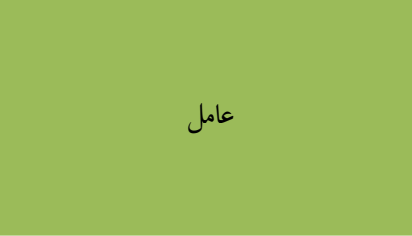 } \\
\hline درصد تجمعى & واريانس بعد از & ال ارزش ويزّه & درصد تجمعى & واريانس قبل از & ارزش ويزْه & \\
\hline $\mid r / r$ & $1 \pi / \mu$ & f & $r Y / \Lambda$ & $r Y / \Lambda$ & $9 / 1$ & زيرساختها و حمايت بيرونى \\
\hline$r \Delta / \Delta$ & $I r / Y$ & $r N$ & rAN & 4 & $1 / 1$ & 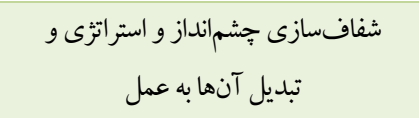 \\
\hline$r \Delta / \Lambda$ & $1 . \mu$ & $r / 1$ & $\kappa \% / 1$ & $\Delta / r$ & 1/9 & به اشتراك كذارى و برقرارى جريان دادهها \\
\hline ra & $9 / r$ & $r / \Lambda$ & FAN & $r / r$ & $1 / \pi$ & برنامهريزى و تنظيم مقاصد \\
\hline$\Delta r / \Delta$ & $\mathrm{V} / \Delta$ & $r / r$ & $\Delta r / \Delta$ & $4 / 1$ & $1 / r$ & بازخوردو يادكيرى استراتزيكك \\
\hline
\end{tabular}

جدول ع: ميانكين و انحر اف معيار كويه هاى يرسشنامه عوامل مرتبط بر كنترل استراتزيك در مراكز بيمارستانى

\begin{tabular}{|c|c|c|c|}
\hline انحر اف معيار & 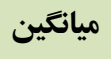 & متغيرها & رديف \\
\hline 194 & $F / \Delta$ & نهادينه شدن فرايند مديريت استراتزيك & Q1 \\
\hline $1 F \Delta$ & $F / \Lambda$ & مشار كت يزشكان در برنامهريزى و اجرا & Q2 \\
\hline .Nr & $F / F$ & بازنخرى هاى بهنكام در برنامه & Q3 \\
\hline /ar & F/l & انعطافيذيرى و يويايى در برنامه & Q4 \\
\hline /qr & $4 / 1$ & امكانات و منابع مالى كافى & Q5 \\
\hline 194 & $r / \Delta$ & درك مشتر كك مديران و كار كنان از استراتزى & Q6 \\
\hline 194 & $F / \Delta$ & يكيار تخى برنامه استراتزيك و همراستايى با سازمانهاى بالادستى & Q7 \\
\hline NF & $F / r$ & هماهنخى و همسويى درونى در بين واحدها و افراد & Q8 \\
\hline .Nr & $F / 1$ & تو انمندسازى سرمايههاى انسانى & Q9 \\
\hline JAF & F/l & تشويق و ترويج كار تيمى & Q10 \\
\hline . NG & F/l & طراحى و به كار كيرى سنجهاى مناسب & Q11 \\
\hline N. & $r / r$ & تعادل و هماهنگى در اهداف استراتزيكك & Q12 \\
\hline Nr & $F / r$ & آموزش و ايجاد دانش و آكاهى & Q13 \\
\hline$/ \wedge 9$ & $k / 1$ & تبديل جشم انداز به يروز ههاى اجرايى مشخص & Q14 \\
\hline Nr & $F / r$ & 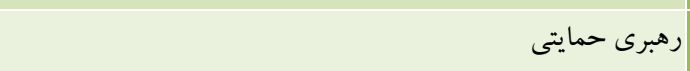 & Q15 \\
\hline NG & $4 / 1$ & شفافيت در نقشها و اختيارات & Q16 \\
\hline 191 & r/9 & تعهد و مسئوليت يذيرى مديران ارشد & Q17 \\
\hline /Ar & $F / 1$ & مديريت عملكرد بر بايه تحقق اهداف استراتزيكك & Q18 \\
\hline
\end{tabular}


ادامه (جدول ع)

\begin{tabular}{|c|c|c|c|}
\hline انحراف معيار & ميانتين & متغيرها & رديف \\
\hline.$/ 9 F$ & $r / \Lambda$ & توجه به كلو كاهها و موضوعات استر اتزيك & Q19 \\
\hline. $\mathrm{VA}$ & $F / 1$ & مباحثهاى فعال و منظم درباره دستاوردهاى اجرا در جلسات روتين بخشها و كل بيمارستان & Q20 \\
\hline.$/ \mathrm{M}$ & $F / r$ & طراحى و استقرار مدل مديريت استراتزيك بومى در بيمارستان & Q21 \\
\hline.$V \Delta$ & f & آكاهى از موانع اجراى برنامههاى استر اتزيكى & Q22 \\
\hline.$/ 99$ & $\varphi / 1$ & دركير شدن ذينفعان كليدى در فرايند مديريت استراتزيك & Q23 \\
\hline /Ar & $F / r$ & 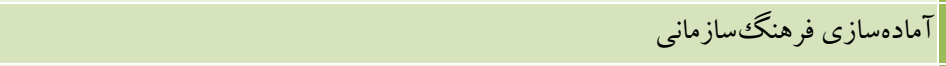 & Q24 \\
\hline.$v r$ & $f / 1$ & ايجاد و رشد تفكر نظاممند و استراتزيكك در مديران و كار كنان & Q25 \\
\hline /Ar & $F / r$ & وجود حمايت سازمانهاى بالادست & Q26 \\
\hline. $\mathrm{VV}$ & $F / l$ & شفافيت در اهداف و استراتزىها & Q27 \\
\hline
\end{tabular}

Scree Plot

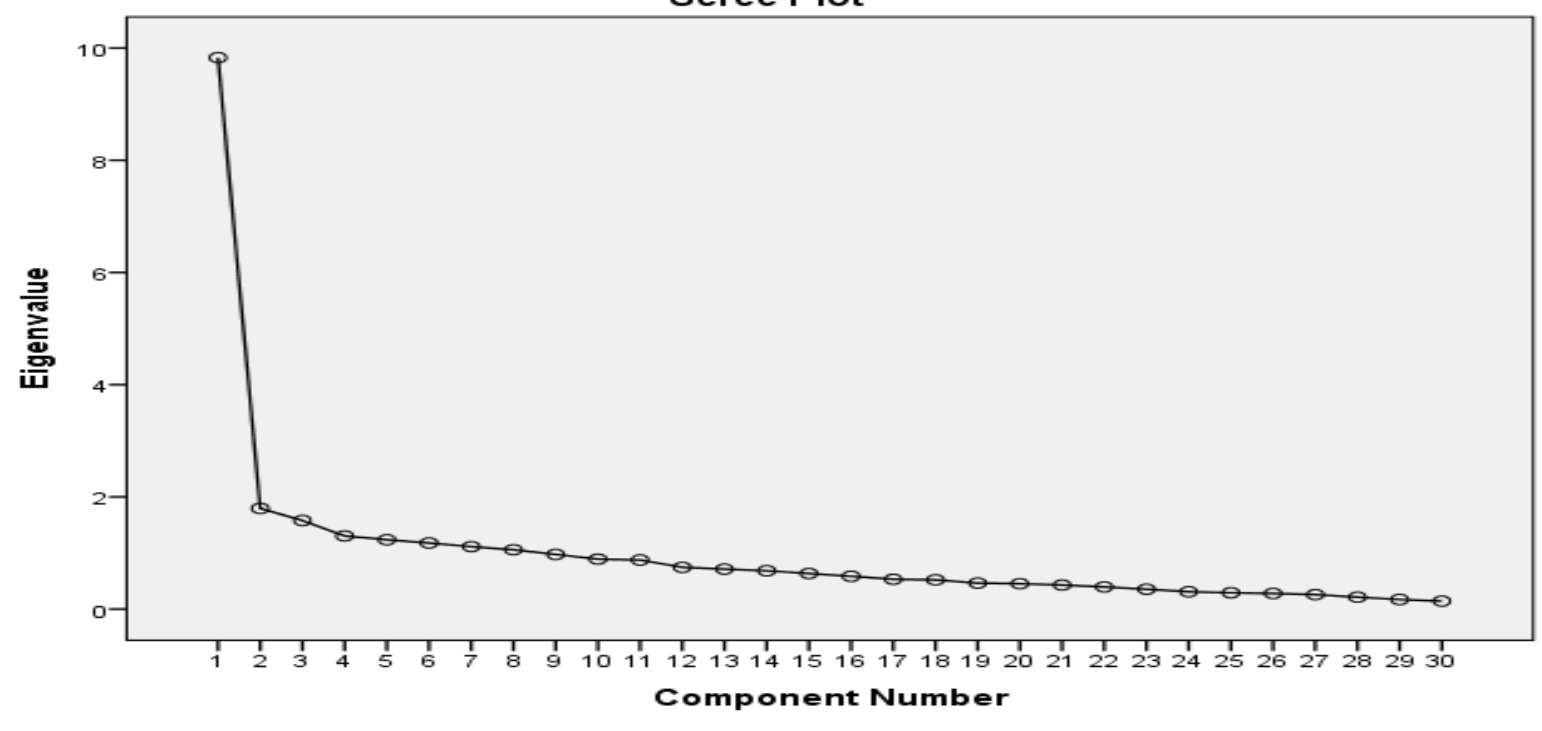

شكل ا: ارزش ويزه حاصل از اجراى تحليل عاملى

يادگيرى استراتزيك دستهبندى شدند. نتايج مطالعات انجام گرفته در مراكز بيمارستانى نيز به عوامل مشابهى در خصوص عوامل مؤثر بر كنترل استراتزيكك دستيافتهاند. بهعنوان نمونه بهادرى و همكاران در مطالعه خود بنج عامل آكاهى و جلب مشاركت مديريت ارشد سازمان، ايجاد و حفظ مشاركت تيمى، بذيرش كار كنان، ساختار سازمانى و فرهنك سازمانى در فر آيند برنامهريزى استراتزيك را إزجمله عوامل مؤثر در كنترل استراتزيك عنوان نمودهاند. [YF]

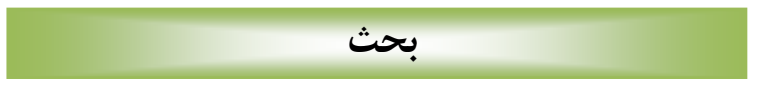

مطالعه حاضر باهدف شناسايى و تحليل اكتشافى عوامل مرتبط با كنترل استراتزيكك در مراكز بيمارستانى به انجام رسيد. بر اساس نتايج مطالعه حاضر عوامل مرتبط با كنترل استراتزيكك در مراكز بيمارستانى در ينج گروه زيرساختها و حمايت بيرونى، شفافسازى جشمانداز و استراتزى و تبديل آنها به عمل، به اشتراك گذارى و برقرارى جريان دادهها و دانش، برنامهريزى و تنظيم مقاصد و بازخورد و 
كه مديران در برنامهريزى و سازماندهى فعاليتهاى مرتبط با اجراى استراتزى دارند، بزرگت ترين مانع اجراى استراتزى، رهبرى ضعيف است. [rr] مطالعهاى در زيمباوه نيز نشان داد مشاركت يايين مديريت در اجراى استراتزى تنها منجر به موفقيت استراتزىهاى جزئى شده و استراتزىهاى كلى و مهم به موفقيت دست نخو اهد يافت. [سر] مديريت ارشد بايد استراتزى و جشم/انداز سازمان را به شكل ساده، شفاف و قابلدركك به كليه كاركنان سطوح مختلف توضيح دهد و به گونهاى ترجمه نمايد تا جشمانداز و استراتزى در امور

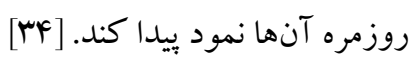
درمجموع نيز نتايج يزوهش حاضر نشان داد كه يرسشنامه كنترل استراتزيكك استفاده شده در اين مطالعه مىتواند بهعنوان يكك ابزار رواو بايا براى بررسى صحت تدوين، اجرا و يايش و ارزشيابى استراتثىها در مراكز بيمارستانى استفاده

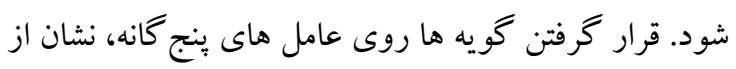
تائيد ساختار نظرى واصلى برسشنامه دارد. از طرفى مقادير

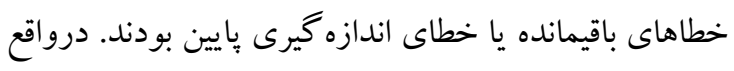
اين نوع خطا، يك خطاى ذاتى است كه تا حدى در همه ابزارهاى تحقيقى وجود دارد و با ساختارهاى ينهان زمينه ارتباطى ندارد. در كل، اين مقادير پيايين باقيمانده بهنوعى برى تائيد كننده اين است كه هر جند ماهيت سؤالات تا حدودى

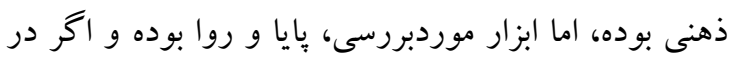
دفعات مختلف از اين ابزار استفاده شود، نتايج يكسانى را

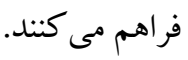
در خصوص پِيايى ابزار نيز مقدار آلفاى كرونباخ بهدست آمده براى ابزار، برابر با ه/. بود و لذا ابزار مطالعه

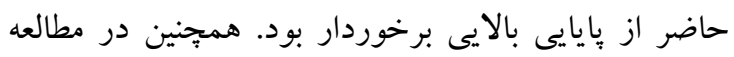
حاضر افراد شركت كننده در پزّوهش ميزان اهميت عوامل مرتبط با كنترل استراتزيكك در مر اكز بيمارستانى را به ترتيب،

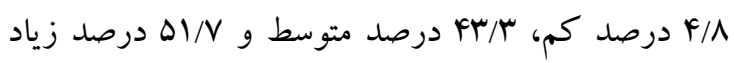
كز ارش كرده بودند. همسو با نتايج مطالعه حاضر، در مطالعه مى هيج و همكار ان تحت عنوان تحليل اجر اي مفهوم مديريت استراتزيكك در سيستم مراقبتهاى سلامت صربستان، وضعيت موجود مديريت استراتزيكك در سام موسسه بهداشتى
عامريون و همكاران [YD] و مصدق راد و همكاران [YY] نيز در بيمارستانهاى كرمان و تهران عوامل انسانى، فرآيند، ساختارى، مديريتى، فرهنكى و نهادى را مؤثر دانستهاند. سيادت و همكاران نيز در شناسايى و تبيين عوامل مؤثر بر كنترل استراتزيكك در صنعت بيمه به روش تحليل عاملى نشان دادند سطوح بلوغ و حرفهاى گرايى سازمان، باورها و عقايد، تحقق كنترل استراتزيكك با رويكرد خودكنترلى، عوامل محيطى، كنترل محتوايى و فرآيندى استراتثىها و توسعه كنترلهاى درونى در سازمان ازجمله عوامل تأثير كذار است.

در بين عوامل بنج گانه، عامل زيرساختها و حمايت بيرونى بالاترين ارزش ويزه را كسب نمود. در مطالعه اسلتر بانفوذترين عامل در موفقيت سازمانى را ارتباط مناسب بين استر اتزىها و معمار سازمانى است. [YN] ماتانداو اوينگك [Y [Y] و همجينين بهيمانى و لانكَفيلد [ [ץ] نيز در مطالعات خود بيان داشتند زيرساخت ها نقش مهمى در اجراى استراتثىها و موفقيت سازمان داشته است. با توجه به اينكه زيرساختها همان فرآيند تصميم گيرى، وضوح نقشها و مسئوليتها، تخصيص منابع انسانى و تعيين سطح انعطاف يذيرى يك تمك سازمان براى ياسخ به شر ايط غير منتظره است [ [M]، لذا ساختار سازمانى و زيرساخت ها از طريق ابزارهاى مورداشاره ميزان اجر ايى شدن استراتزىها را افزايش مىدهد. عامل شفافسازى جشمهانداز و استراتزى و تبديل آنها به عمل نيز بهعنوان دومين عامل مؤثر در ارتباط با كنترل استراتزيكك شناخته شد. با توجه به اينكه يكى از مهمترين عوامل مورد تأكيد در نظام كنترل استراتزيك، ايجاد يك فر آيند شفاف در تعيين جشمانداز و استراتزى بيمارستان و تبديل اين مقوله هاى ذهنى به بروزههاى عملياتى مشخص است، اين جنبه كنترل استراتزيكك بيشتر ناظر به كنترل تدوين برنامه است به گونهاى كه به دنبال حصول اطمينان نسبت به تدوين صحيح استراتزىها است. بعىترديد يكى از راهكارها در اين خصوص، جلب مشاركت مؤثر و مداوم مديريت ارشد سازمان است. كاتر و يوكو در مطالعهاى بر روى IVY شركت اسلوونيايى، نشان دادند كه با توجه به نقشى 
بود جر اكه تعداد بيمارستانهاى موردمطالعه YF مركز بود كه ممكن است بر نتايج كلى اثر كذار باشد و جنانجه تعداد بيمارستانهاى انتخابى بيشتر باشد شايد احتمال سو گرايى ناشى از دادهها را كاهش دهد.

\section{ملاحظات اخلاقى}

رعايت دستور العمل هاى اخلاقى: اين بزٔوهش با كد

اخلاق به شماره IUMS/SHMIS-2012/527

$$
\text { اخذشده از كميته اخلاق در يزوهشهده استى زيست يزشكى }
$$

حمايت مالى : اين ثئوهش با حمايت مالى دانشگاه علوم

$$
\text { يزشكى ايران، تهران، ايران انجامشده است. }
$$

تضاد منافع: نويسندكان اظهار داشتند كه تضاد منافعى

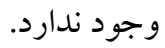

تشكر و قدردانى: در يايان از مسئولين و كاركنان بيمارستانهاى آموزشى درمانى دانشگاههاى علوم يزشكى لئى تهران و ايران كه صميمانه در اجراى اين طرح همكارى نمودهاند، سياسگز ارى مى گردد.
درمانى موردمطالعه قرار داده و يكك مدل مناسب براى تسهيل و بهبود اين فر آيند را ارائه كردهاند و نشان دادهاند كه سازمانهاى مراقبت سلامت در صربستان، از شيوههاى تحليل استراتزيكك استفاده مى كنند. [F] نتايج مطالعه فوق بامطالعه حاضر همخوانى دارد. در مطالعه حاضر، محقق با استفاده از يكك يرسشنامه محقق ساخته و با استفاده از افراد مطلع درزمينه مديريت استراتزيك در بيمارستانها به اهميت موضوع برداخته بود. در مطالعه حاضر اكثر شركت كنند گان به اهميت زياد عوامل مرتبط با كنترل استراتزيك در مراكز بيمارستانى اهميت زيادى اشاره كردند كه مىتواند نشاندهنده اين باشد كه اين برنامه از الزامات وزارت بهداشت در مراكز درمانى باشد ولى براى اجراى اين طرحها نيازمند منابع مالى فراوانى باشد كه به نحو احسن اجرا نمى شود. از مزاياى اين ابزار، كوتاه بودن آن است كه سرعت تكميل

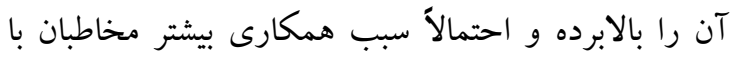
محققين مى شود. ضمن اينكه اختصاصى بودن اين ابزار سبب مىشود عوامل مرتبط با كنترل استراتزيكك در مراكز بيمارستانى به شكل دقيق ترى بررسى شود.

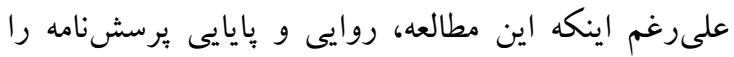

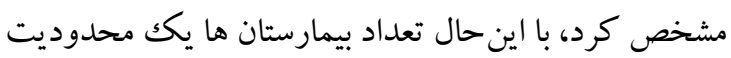

\section{References}

1. Wu W-w, Liang D-p, Yu B, Yang Y. Strategic planning for management of technology of China's high technology enterprises. Journal of Technology Management in China. 2010;5(1):6-25.

2. Lee S, Ko ASO. Building balanced scorecard with SWOT analysis, and implementing "Sun Tzu's The Art of Business Management Strategies" on QFD methodology. Managerial Auditing Journal. 2000;15(1/2):68-76.

3. Candy V, Gordon J. The historical development of strategic planning theories. International Journal of Management \& Information Systems (IJMIS). 2011;15(4):71-90.

4. Zuckerman AM. Healthcare strategic planning: Health Administration Press; 2005.

5. Mintzberg H, Ahlstrand B, Lampel J. Strategy Safari: A Guided Tour Through The Wilds of Strategic Mangament: Simon and Schuster; 2005. 
6. de Hoogh A, den Hartog D, Koopman P, Thierry H, van den Berg P, van der Weide J, et al. Charismatic leadership, environmental dynamism, and performance. European Journal of Work and Organizational Psychology. 2004;13(4):447-71.

7. Bell $P$, Dean $G$, Gottschalk P. Information management in law enforcement: The case of police intelligence strategy implementation. International Journal of Information Management. 2010;30(4):343-9.

8. Grigoroudis E, Orfanoudaki E, Zopounidis C. Strategic performance measurement in a healthcare organisation: A multiple criteria approach based on balanced scorecard. Omega. 2012;40(1):104-19.

9. Jacobovitz S, Weissman NJ, Soman P. New Strategic Plan Charts Next Chapter in College's History: Implications for the Cardiovascular Imager. JACC: Cardiovascular Imaging. 2014;7(5):537-9.

10. Legge D. The Strategic Control of an Ant-Based Routing System using Neural Net Q-Learning Agents. Adaptive Agents and Multi-Agent Systems II. 2005:147-66.

11. Pratistha B. Building a Strategic Control Model for Space Technology Program in Indonesia. International Journal of Applied Business and Economic Research. 2016;14(2):1327-42.

12. Schreyögg G, Steinmann H. Strategic control: a new perspective. Academy of Management Review. 1987;12(1):91-103.

13. Zamani S, Montazeri M. The relationship between job security and mental health staff of railway Hormozgan. Railway Research Center. 2013;244:1-6. [In Persian]

14. Thompson B. Exploratory and confirmatory factor analysis: Understanding concepts and applications. Washington, DC. 2004, https://doi.org/10.1037/10694-000.

15. Gefen D, Straub D, Boudreau M-C. Structural equation modeling and regression: Guidelines for research practice. Communications of the association for information systems. 2007;4(1):7.

16. Hoe SL. Issues and procedures in adopting structural equation modeling technique. JAQM. 2008;3(1):76-83.

17. Pett MA, Lackey NR, Sullivan JJ. Making sense of factor analysis: The use of factor analysis for instrument development in health care research: Sage publication; 2003.

18. Tabachnick BG, Fidell LS. Using Multivariate Statistics: Pearson Education Inc. Boston, MA. 2007.

19. Comrey AL, Lee HB. A first course in factor analysis: Psychology Press; 2013.

20. Newman I, Lim J, Pineda F. Content validity using a mixed methods approach: Its application and development through the use of a table of specifications methodology. Journal of Mixed Methods Research. 2013;7(3):243-60. 
21. Abdollahpour I, Nedjat S, Noroozian M, Majdzadeh R. Performing Content Validation Process in Development of Questionnaires. Iranian Journal of Epidemiology. 2011;6(4):66-74. [In Persian]

22. Streiner DL, Norman GR. Health measurement scales: a practical guide to their development and use: Oxford university press; 2008.

23. Watkins MW. Exploratory factor analysis: A guide to best practice. Journal of Black Psychology. 2018;44(3):219-46.

24. Bahadori M, Teymourzadeh E, Tajik H, Ravangard R, Raadabadi M, Hosseini SM. Factors affecting strategic plan implementation using interpretive structural modeling (ISM). International journal of health care quality assurance. 2018;31(5):406-14.

25. Ameryoun A, Shahabinejad M, Ghiasi AR, Soltani PS. Barriers to Implementation of the Strategic Plan from the Perspective of Managers in Military and non Military Hospitals of Kerman. Journal of Police Medicine. 2016;5(1):47-54. [In Persian]

26. Mosadeghrad AM, Isfahani P. The Challenges of Strategic Planning in Tehran Province Hospitals. Management Strategies in Health System. 2018;3(3):184-200.

27. sayadat $\mathrm{s}$, amini $\mathrm{mt}$, parhizghar $\mathrm{mm}$, salar $\mathrm{j}$. Identification and explanation of the effective factors influencing on the strategic control utilizing self-control approach in the insurance industry. Scientific Journal Management System. 2019;25(72):157-79. [In Persian]

28. Slater SF, Olson EM. Marketing's contribution to the implementation of business strategy: An empirical analysis. Strategic Management Journal. 2001;22(11):1055-67.

29. Matanda T, Ewing MT. The process of global brand strategy development and regional implementation. International Journal of Research in Marketing. 2012;29(1):5-12.

30. Bhimani A, Langfield-Smith K. Structure, formality and the importance of financial and nonfinancial information in strategy development and implementation. Management Accounting Research. 2007;18(1):3-31.

31. Rajasekar J. Factors affecting effective strategy implementation in a service industry: A study of electricity distribution companies in the sultanate of oman. International Journal of Business and Social Science. 2014;5(9):169-83.

32. Čater T, Pučko D. Factors of effective strategy implementation: Empirical evidence from Slovenian business practice. Journal for east european Management Studies. 2010:207-36.

33. Mapetere D, Mavhiki S, Nyamwanza T, Sikomwe S, Mhonde C. Strategic role of leadership in strategy implementation in Zimbabwe's state owned enterprises. International Journal of Business and Social Science. 2012;3(16):271-6.

34. Irala D, Reddy L. Performance Measurement Using Balanced Score Card. Performance Measurement Using Balanced Score Card (April 10, 2007). 2007. 